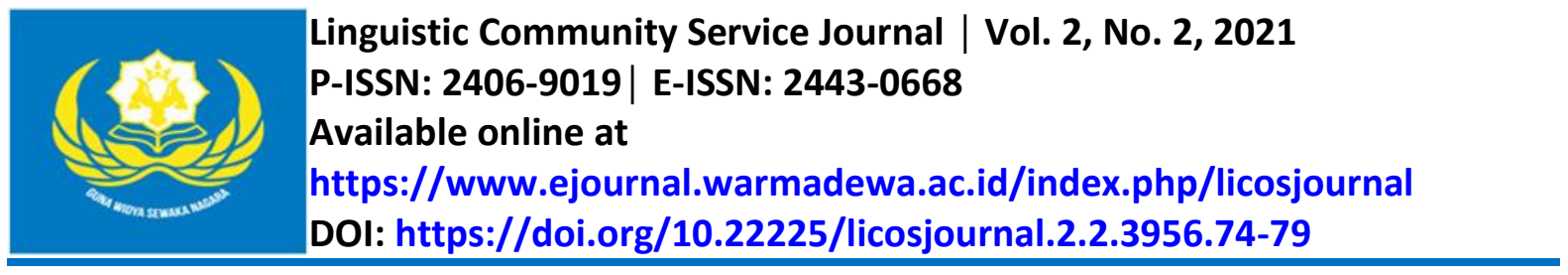

\title{
PENTINGNYA PENGUASAAN FUNGSI- FUNGSI BAHASA INGGRIS DALAM BERBICARA
}

\author{
Ni Wayan Kasni \\ Universitas Warmadewa, Denpasar, Bali-Indonesia \\ wayankasni@gmail.com
}

\begin{abstract}
Abstrak
Kelompok belajar Akasia merupakan kelompok belajar Bahasa Inggris siswa SD dan SMP yang berada di dekat kampus Universitas Warmadewa. Pengabdian kepada mesayarakat ini dilaksanakan pada kelompok belajar Akasia dalam bentuk kegiatan pengajaran bahasa Inggris. Sehingga tujuan kegiatan pengabdian kepada masyarakat ini adalah untuk meningkatkan keterampilan berbicara Bahasa Inggris siswa-siswa di kelompok belajar Akasia. Metode yang diterapkan pada kegiatan tersebut adalah metode Communicative Language Taeching in Secondary Level. Di samping itu, kegiatan ini dilaksanakan melalui aplikasi Zoom. Pada kegiatan pengabdian tersebut, siswa kelompok belajar Akasia antusias dan aktif untuk mengikuti pembelajaran atau pelatihan. Siswa pada kelompok belajar Akasia diberikan beberapa fungsi Bahasa Inggris yang sering dipakai, yaitu greeting, asking name, dan asking date, time, day year.
\end{abstract}

Kata Kunci: Berbicara, Fungsi Bahasa, Kelompok Belajar

\begin{abstract}
The Akasia study group is an English learning group for elementary and junior high school students located near the Warmadewa University campus. This community service is carried out in Akasia study groups in the form of English language teaching activities. Therefore, the purpose of this community service activity is to improve the English speaking's skills of students in the Akasia study group. The method applied to this activity is the Communicative Language Taeching in Secondary Level method. In addition, this activity is carried out through the Zoom application. In these service activities, the students of the Akasia study group were enthusiastic and active in participating in learning or training. Students in the Akasia study group were given several English functions that were often used, namely greeting, asking name, and asking date, time, day year.
\end{abstract}

Keywords: Speaking, Language Function, Study Group

\section{PENDAHULUAN}

Bahasa Inggris di Indonesia telah menjadi media yang sangat penting dalam komunikasi. Bahasa Inggris berperan sebagai bahasa global atau dunia (Crystal, 2003). Peran bahasa Inggris dapat dilihat dalam berbagai bidang seperti pada dunia pariwisata, pendidikan, ekonomi, bahkan dalam dalam komunikasi sehari-hari. Hal ini menunjukkan bahwa kebutuhan terhadap bahasa Inggris di Indonesia sangat penting sekali.

Kedudukan bahasa Inggris di Indonesia adalah sebagai bahasa kedua. Sebagai bahasa kedua, bahasa Inggris digunakan dalam tujuan tertentu seperti tujuan akademis, peningkatan karir, dan juga untuk kebutuhan perjanan ke luar negeri. Selain itu, Bahasa Inggris sebagai bahasa asing pertama yang dipelajari sebagai mata pelajaran wajib dari sekolah menengah pertama hingga perguruan tinggi di Indonesia (Nurcahyani, 2020). Pentingnya bahasa Inggris di Indonesia membuat pemerintah khususnya melalui Menteri Pendidikan dan Kebudayaan memasukkan mata pelajaran bahasa Inggris mulai dari sekolah dasar. Hal ini dimaksudkan agar para siswa mengenal dasar-dasar bahasa Inggris mulai sejak dini, yaitu saat mereka mengenal bangku sekolah.

Berbicara mengenai bahasa Inggris, terdapat 4 (empat) keterampilan yang harus dikuasai dalam belajar bahasa Inggris (Kusuma, Zakaria \& Djuwita, 2017). Keempat keterampilan tersebut adalah keterampilan mendengarkan, keterampilan berbicara, keterampilan membaca, dan keterampilan 
menulis. Keterampilan mendengarkan dan membaca disebut receptive skills karena pembelajar tidak perlu memproduksi bahasa, mereka hanya menerima dan memahami saja. Keterampilan berbicara dan menulis disebut productive skills karena pembelajar perlu memproduksi bahasa.

Dalam dunia komunikasi sehari-hari keterampilan yang paling penting untuk dikuasai adalah keterampilan berbicara. Mengajar keterampilan berbicara bukanlah merupakan hal mudah yang dipengaruhi oleh sejumlah faktor (Brown, 2000). Para pengajar menemukan beberapa kesulitan atau masalah di antaranya (1) beberapa siswa takut untuk membuat kesalahan, (2) beberapa siswa tidak memperoleh kesempatan uintuk terlibat dalam aktivitas berbicara dalam kelas, (3) ada beberapa siswqa yang pasif, sehingga mereka enggan untuk terlibat dalam aktivitas speaking, (4) kadangkadang topik yang disajikan kurang menarik, (5) beberapa siswa kadang-kadang berbicara terlalu kecil dan pelan. Dari beberapa permasalahan yang dihadapi oleh pengajar, beberapa hal yang harus diatasi oleh seorang pengajar adalah sabar dan mendorong mereka untuk mau berbicara dan mengoreksi hanya pada kesalahan-kesalahan yang bersifat serius, berbicara kepada siswa setelah pelajaran selesai, berikan mereka perhatian dan bnatu mereka, memperbaharui materi ajar, dan mendorong mereka untuk berbicara keras.

Berbicara adalah kemampuan mengucapkan bunyi-bunyi artikulasi atau kata-kata untuk mengekspresikan, menyatakan serta menyampaikan pikiran, gagasan, dan perasaan (Tarigan, 2013). Aktivitas dalam pelajaran keterampilan berbicara meliputi tiga kegiatan yang harus diterapkan oleh seorang pengajar (Budiarso, 2019). Ketiga kegiatan tersebut meliputi (1) siswa membuat kalimat tentang diri mereka sendiri, (2) pengajar menggunakan metode asking and answering yang dapat dilakukan secara bergiliran dan dapat menyuruh sisswa menanyakan teman yang lainnya. He/she tells a learner to ask another learner one question. (3) pengajar memberikan pertanyaan dan mendorong siswa untuk memberikan jawaban yuang singkat dan realistis. Para guru dapat menyuruh siswa untuk memberikan jawaban lebih dari satui kalimat. Para pengajar membrikan jawaban yang nyata dan menyuruh siswa untuk membuat pertanyaan.

Pengingkatan keterampilan berbicara tidak semata-mata mengandalkan pelajaran yang diberikan di sekolah. Banyak anak-anak pencinta bahasa Inggris yang mengasah kemampuan berbicaranya dengan mengikuti kegiatan-kegiatan di luar sekolah seperti les bahasa Inggris. Tetapi ada juga yang sangat menarik adalah membentuk kelompok belajar. Salah satu kelompok belajar yang ada dekat kampus Universitas Warmadewa adalah kelompok belajar Akasia yang berlokasi di jalan Akasia Denpasar. Kelompok belajar ini merupakan kelompok belajar yang sangat tertarik dengan bahasa Inggris. Anggotanya adalah siswa SD dan SMP. Pemasalahan yang diangkat untuk meningkatkan kemampuan berbicara kelompok belajar Akasia adalah penting penguasaan fungsifungsi bahasa Inggris dalam kemampuan berbicara. Fungsi-fungsi bahasa Inggris yang diberikan antara lain greeting, asking name, dan asking date, time, day, year.

\section{METODOLOGI}

Dalam memberikan pengajaran bahasa Inggris, pengajar menggunakan metode asking and answering, group work, telling stories. Dalam hal ini metode yang diterapkan adalah Communicative Language Taeching in Secondary Level. Communicative Language Teaching adalah sebuah metode yang didasarkan pada target mengajar dan pembelajaran bahasa untuk komunikasi kehidupan nyata dan efektif (Seraj \& Mamun, 2011). Metode pembelajaran CLT merupakan serangkaian langkah pengajaran yang menitikberatkan pada pembelajaran bahasa yang komunikatif (Richards \& Rodgers, 2001). Lima karakteristik penerapan metode CLT, yaitu: 1) appropriateness, 2) message focus, 3) psycholonguistic processing 4) risk taking dan 5) free practice (Johnson \& Johnson, 1998). Metode CLT ini diterapkan karena ada keterbatasan ruang yaitu, kegiatan dilaksanakan pada saat pandemic covid-19, sehingga sentuhan langsung kepada siswa baik untuk mendorong peserta untuk berbicara dan aktif dalam kegiatan berbicara agak terbatas karena kegiatan dilaksanakan melalui aplikasi Zoom.

\section{HASIL DAN PEMBAHASAN}

Untuk meningkatkan keterampilan bahasa Inggris kelompok belajar Akasia, mereka dibekali beberapa fungsi bahasa Inggris yang sering dipakai sehari-hari-hari. Fungsi-fungsi bahasa Inggris yang diberikan adalah fungsi-fungsi dasar yang meliputi greeting, asking name, dan asking date, time, day, year. 


\section{a. Greeting}

Greeting merupakan sebuah ungkapan yang biasanya digunakan oleh seseorang untuk melakukan tegur sapa atau salam dengan orang lain (Shields-Lysiak et al., 2020). Berdasarkan situasinya, greeting dapat dibedakan menjadi 2 (dua) yaitu formal dan informal.

\section{Informal greeting}

Berikut adalah contoh-contoh informal greeting beserta resposnya.

\section{Informal Greetings}

What's up? (Ada apa?)

It's good to see you? / Good to see you?

(Senang berjumpa denganmu? / Senang melihatmu?)

How are things with you? (Bagaimana kabarmu?)

How is it going? (Apa kabar?)

How is life been treating you?/ How's life? (Bagaimana kabarmu?

What's new with you? (Apa yang kabar tebarumu?)

What's cracking? (Apa kabar?)

What's cooking? (Memasak apa?

How have you been? (Bagaimana kabarmu?)

\section{Responses}

Pretty well

Good to see you too.

Ok, not bad.

Well, nothing special.

It's pretty good, thanks.

Nothing much.

Awesome

Nice

I have been fine.

Setelah anak-anak diberikan contoh-contoh greeting yang bersifat informal, selanjutnya mereka mempraktekannya dengan pasangan mereka.

\section{Formal Greeting}

Berikut contoh sapaan formal (Greetings Formal) beserta cara meresponnya.

\section{Formal Greetings}

Hello

Good Morning/ Good Afternoon/ Good Evening

How are you?

How are you doing?

How is everything?

How do you do (first meeting)

Nice to meet you.

\section{Responses}

Hello

Good Morning/Good Afternoon/Good Evening

I am fine, thank you.

I'm doing well, thank you.

Everything is fine, thank you.

How do you do

Nice to meet you.

Metode yang diterapkan dalam mengajarkan formal greeting adalah sama dengan metode pada informal grereting. Para siswa diberikan kesempatan untuk mempraktekkan secara singkat tentang formal greeting.

\section{b. Asking name}

Menanyakan nama seseorang dalam bahasa Inggris atau asking about names merupakan salah satu bentuk fungsi bahasa Inggris yang sering dipakai dalam percakapan sehari-hari. Cara menanyakan nama seseorangpun dibedakan menjadi 2 (dua) berdasarkan situasi yaitu formal dan informal.

Berikut ini dalah ungkapan yang digunakan untuk menanyakan nama seseorang

- What is your name? = Siapa nama Anda? (bentuk paling biasa)

- What is your name? If you don't mind I'm asking = Siapa nama Anda? Bila Anda tidak keberatan saya bertanya demikian (sopan)

- What should I call you? = Saya harus memanggil Anda siapa?

- How do I call you?

- How is one to call you?

- $\quad$ Could I ask for your name? = Bolehkan saya tahu nama Anda?

- $\quad$ May I know you name? = Bolehkan saya tahu nama Anda? (Lebih sopan) 
- What was your name again? = Tadi siapa nama Anda? (lebih sopan, juga biasa digunakan saat lupa nama orang yang sebelumnya sudah memperkenalkan diri)

- May I have your name? = Boleh saya tahu nama Anda? (sangat sopan tetapi jarang digunakan dalam berbagai konteks percakapan)

- How may I address you? (sangat sopan, ungkapan ini sudah sangat jarang digunakan dalam konteks percakapan karena dahulu biasa digunakan oleh para penduduk Inggris kuno)

- How do you spell your name? = Bagaimana caranya mengeja nama Anda?

Ungakapan yang digunakan untuk merespon dan menjawab pertanyaan sesorang yang bertanya tentang nama kita

- $\quad$ My name is Ika = Nama saya Ika

- $\quad$ Mine (name) is Ika = Nama saya Ika

- $\quad$ My nick name is Ana = Nama panggilan saya Ana

- It's Wayan = Nama saya Wayan

- $\quad$ My full name is Wayan Anika = Nama lengkap saya Wayan Anika

- $\quad$ You can call me Anik = Anda bisa memanggil saya Anik

- Usually people call me Dewi = Biasanya orang-orang memanggil saya Dewi

Para siswa diberikan kesempatan untuk mempraktekan pertanyaan-pertanyaan tersebut dan mereka memberikan jawaban sesuai dengan nama mereka masing-masing.

\section{c. Asking time, day, date, year}

Ada banyak cara untuk menyampaikan waktu/jam dalam bahasa Inggris. Berikut adalah beberapa cara menyampaikan waktu dalam bahasa Inggris:

1. Dengan cara mengucapkan jam terlebih dahulu baru diikuti dengan menitnya

Perhatikan contoh di berikut ini!

5:10 - Five Ten

6: 30 - Six Thirty

8: 45 - Eight forty-five

Untuk bilangan 0-09, kita bisa mengucapkannya dengan 'oh'

Misalnya: 4:04 - Four (oh) four.

2. Dengan cara mengucapkan menitnya terlebih dahulu kemudian baru jamnya

Dalam hal ini kata past jika menitnya 01-30

Contoh:

4:10 - Ten past four (jam 4 lewat 10 menit)

7:20 - Twenty past seven (Jam tujuh lewat dua puluh menit)

11: 25 - Twenty five past eleven (jam 11 lewat 25 menit)

Selanjutnya kata to untuk menit 31-59

Contoh:

4: 35 - twenty five to 5 (jam 5 kurang 25 menit)

7: 50 - Ten to eight (jam 8 kurang 10)

10: 40 - Twenty to eleven (jam 11 kurang 20)

30 menit $=$ half, 15 menit $=$ a quarter dalam bahasa Inggris.

Contoh:

1: 15 - a quarter past one

4: 30 - half past four

$3: 45$ - a quarter to four

6:30 - half past six

7:45 - a quarter to eight 
a.m. dan p.m.

a.m. dan p.m. sering dipakai dalam menyampaikan jam. a.m. (ante merediem) dipakai untuk waktu sebelum siang atau sesudah siang yaitu antara pukul 00:00 sampai pukul 12:00 siang. p.m. (post merediem) dipakai untuk waktu antara pukul 12:00 siang sampai 00:00. Untuk a.m. atau p.m. digunakan/ dirangkai berbarengan cara penyampaian waktu pada cara ke 1 di atas. Kata in the morning, in the afternoon, in the evening, atau at night dapat digunakan untuk menggantikan kata a.m. dan p.m.

Contoh: 7:15 (a quarter past seven in the morning/ a quarter past seven in the evening).

Pertanyaan yang sering dipakai untuk menanyakan jam antara lain:

What time is it?

What's the time?

4. The names of days

Nama-nama hari dalam bahasa Inggris:

Sunday (Minggu)

Monday (Senin)

Tuesday (Selasa)

Wednesday (Rabu)

Thursday (Kamis)

Friday (Jum'at)

Saturday (Sabtu)

5. Date

Bahasa Inggris Amerika

Dalam bahasa Inggris Amerika menuliskan tanggal hanya dengan menggunakan angka. Bentuk yang paling umum adalah: 5/10/04

Perlu diperhatikan bahwa 5/10/04 biasanya berarti tanggal 5 Oktober 2004 dalam bahasa Inggris British, dan dalam bahasa Inggris Amerika bisa berarti tanggal 10 Mei 2004. Untuk menghindari kerancuan ini, anda harus mengeja bulan atau menggunakan singkatan.

Tanggal dalam bahasa Inggris lisan

Jika kita menempatkan hari sebelum bulan, gunakan the sebelum hari dan preposisi of sebelum bulan. 5 October $2004=$ The fifth of October, Two thousand and four

Jika kita menempatkan bulan sebelum hari, gunakan the sebelum hari (bahasa inggris British) atau the bisa dihilangkan (bahasa inggris Amerika).

October 5, 2004 = October (the) fifth, two thousand and four

Cara mengucapkan tahun

Mulai tahun 2000 ke atas, tahun dieja seperti bilangan biasa.

$2000=$ two thousand

$2003=$ two thousand and three

Untuk tahun 2000 ke belakang, tahun dieja berbeda: dua angka pertama adalah satu bilangan dan dua angka terakhir adalah satu bilangan. Kedua satuan bilangan ini bisa digabungkan dengan hundrend and, yang sebenarnya hanya perlu jika dua angka terakhir adalah 00 sampai 09.

$1999=$ nineteen ninety nine

$1998=$ nineteen ninty eight

$1806=$ eighteen hundred and six/eighteen oh six

Dalam mengajarkan date, day, date, dan year, siswa juga mempraktekkan pertanyaan-pertanyaan dengan pasangannya dan pasangannya menjawab sesuai dengan kenyataan.

\section{IV.SIMPULAN}

Berdasarkan tiga jenis fungsi-fungsi bahasa Inggris yang diberikan kepada siswa kelompok belajar Akasia, para siswa berantusias sekali mengikuti pelatihan terutama ketika mereka diberikan 
kesempatan untuk mempraktekkannya. Ketiga fungsi Bahasa Inggris tersebut yaitu greeting, asking name, dan Asking date, time, day, year. Harapan siswa di kelompok belajar tersebut adalah kegiatan pengajaran dapat berjalan lagi sehingga mereka memperoleh pengetahuan yang lengkap tentang fungsi-fungsi bahasa Inggris.

\section{DAFTAR PUSTAKA}

Brown, H. D. (2000). Principles of language learning and teaching (4th ed.). Longman.

Budiarso, I. (2019). Analisis Metode Communicative Language Teaching Terhadap Kemampuan Berbicara Bahasa Inggris Guru-Guru SMK dan SMP Islam Mandiri Bojong Gede Bogor. Jurnal SAP, 3(3), 239-247.

Crystal, D. (2003). English as a Global Language (2nd ed.). Cambridge University Press.

Johnson, K., \& Johnson, H. (1998). Communicative Methodology. In K. Johnson \& H. Johnson (Eds.), Encylopedic Dictionary of Applied Linguistics. Blackwell.

Kusuma, D., Zakaria, \& Djuwita, P. (2017). Manajemen Pembelajaran Bahasa Inggris dalam Meningkatkan Kemampuan Writing Siswa SMP. Manajer Pendidikan, 11(3), 254-262.

Nurcahyani, A. (2020). Peningkatan Keterampilan Berbicara Bahasa Inggris Melalui Media Flash Card Siswa Kelas 3 SDN Putat 02, Geger, Madiun Tahun Ajaran 2019/2020. Institut Agama Islam Negeri Ponorogo.

Richards, J. C., \& Rodgers, T. S. (2001). Approaches and Methods in Language Teaching (2nd ed.). Cambridge University Press.

Seraj, P. M. I., \& Mamun, M. A. A. (2011). Speaking and Listening Practice in English Language Learning through Communicative Language Teaching at HSC Level. Online Journal of GScience Implementation and Publication, 2(4).

Shields-Lysiak, L. K., Boyd, M. P., Iorio, J. P., \& Vasquez, C. R. (2020). Classroom greetings: More than a simple hello. Iranian Journal of Language Teaching Research, 8(3), 41-56.

Tarigan, H. G. (2013). Menulis: Sebagai Suatu Keterampilan Berbahasa. Angkasa. 